Strahlenther Onkol 2013 · 189:993-995

DOI 10.1007/s00066-013-0459-2

Received: 15 August 2013

Accepted: 11 September 2013

Published online: 2. November 2013

c) Springer-Verlag Berlin Heidelberg 2013
R. Fietkau ${ }^{1}$ - F. Putz ${ }^{1} \cdot$ G. Lahmer ${ }^{1} \cdot$ S. Semrau ${ }^{1} \cdot$ R. Buslei $^{2}$

${ }^{1}$ Klinik für Strahlentherapie, Erlangen

${ }^{2}$ Neuropathologisches Institut des Universitätsklinikums Erlangen und des CCC Erlangen

\section{Can MGMT promoter methylation status be used as a prognostic and predictive marker for glioblastoma multiforme at the present time?}

\section{A word of caution}

\section{Editorial}

Several studies have addressed the prognostic and predictive value of the methylation status of the O6-methylguanineDNA methyltransferase (MGMT) gene in patients with glioblastoma multiforme (GBM). In a translational study analyzing the randomized EORTC-26981-22981/ NCIC-CE3 trial by Stupp et al. [9], Hegi and coworkers [4] first demonstrated that the benefit of combined radiotherapy and temozolomide chemotherapy over radiotherapy alone was significant in GBM patients with a methylated MGMT promoter (median survival: 21.7 versus 15.3 months; $p<0.001$ ), but only slight and borderline significant in those with an unmethylated status (median survival: 12.7 versus 11.8 months; $\mathrm{p}<0.06$ ). MGMT promoter methylation was found to be an independent prognostic factor for survival (hazard ratio: $0.41 ; \mathrm{p}=0.001$ ). However, these initial results were partly offset by the results of a five-year analysis published by the same group at a later date [8]. In the latter study, the addition of temozolomide to radiotherapy also had a significant beneficial effect in patients with an unmethylated MGMT promoter (median survival: 12.6 vs. 11.8 months; $\mathrm{p}=0.035$ ).

The predictive value of MGMT promoter methylation status was also demonstrated in two recent studies on the treatment of elderly GBM patients over 65 [11] and 60 years of age [5]: in the groups treated with temozolomide alone, patients with a methylated MGMT promoter had a better prognosis than those without methylation. Within these groups, the NOA08 trial [11] showed an advantage in terms of event-free survival (median: 8.4 versus 3.3 months; $p=0.01$ ), while the Nordic study by Malmstrom et al. [5] demonstrated an additional benefit in terms of overall survival (median: 9.7 vs. 6.8 months; $\mathrm{p}=0.02$ ). Conversely, MGMT promoter methylation status had no impact among patients treated with radiotherapy alone.

Consequently, there are now frequent demands for the routine use of MGMT promoter methylation as a predictive and prognostic factor in clinical practice. For example, Platten and colleagues [6] stated that the decision to forego radio- or chemotherapy should depend on the methylation status of the MGMT gene. For individuals over 65 years of age, this means that temozolomide chemotherapy alone should be administered in patients with a methylated MGMT promoter and radiotherapy alone in those with an unmethylated MGMT promoter. Nowadays, more and more studies are being designed for the exclusive inclusion of patients with a specific MGMT status (compare the CENTRIC, CeTeG and Glarius studies). This assumes a widespread availability of standardized, reliable and validated methods for the determination of MGMT promoter methylation status.

However, we would like to point out that there are still many uncertainties associated with the practical implementa- tion of MGMT promoter methylation analysis. In our view, it would be premature to use the MGMT status as a biomarker for treatment selection in routine clinical practice at this stage. Our opinion is supported by a recent review published by Berghoff and colleagues in Austria [1].

What are the current arguments against the routine use of MGMT promoter methylation status in clinical practice?

- Various methods for the determination of MGMT promoter methylation status have been developed and are currently available. However, sufficient evidence demonstrating the intra- and interlaboratory reproducibility of any of these tests is still lacking. Therefore, in their clinical neuropathology practice guide, Berghoff et al. demand a scientific analysis of the reproducibility of these tests, stating" This lack of evidence impedes recommendation of MGMT testing for routine clinical use" [1].

- The MGMT gene promoter contains a total of 97 potential CpG methylation sites. However, it is frequently the case that only a small sample (5 to 9) of these sites are analyzed, depending on the analytical method used. The methylation patterns show some heterogeneity between different patients, but there is evidence that the prognostic significance of the individual methylation sites differ [7]. Consequently, the prognostic and predictive value of MGMT status must always be 
Tab. 1 Current studies on 06-methylguanine-DNA methyltransferase (MGMT) gene promoter methylation status in patients with glioblastoma multiforme (GBM)

\begin{tabular}{|c|c|c|c|c|c|c|}
\hline Study & Histopathology & $\begin{array}{l}\text { Analyzed CpG } \\
\text { positions }\end{array}$ & Method & Institution & $\begin{array}{l}\text { Tumor cell } \\
\text { content }\end{array}$ & $\begin{array}{l}\text { Successfully de- } \\
\text { termined MGMT } \\
\text { methylation } \\
\text { status }\end{array}$ \\
\hline $\begin{array}{l}\text { NOA-08 (Wick et } \\
\text { al. [11]) }\end{array}$ & $\begin{array}{l}\text { GBM: } 88.7 \% \\
\text { AA: } 10.7 \% \\
\text { NA: } 0.5 \%\end{array}$ & $\begin{array}{l}\text { 1) CpG 75-79 } \\
\text { and CpG 87-89 } \\
\text { 2) CpG 73-76 } \\
\text { and CpG 86-88 }\end{array}$ & $\begin{array}{l}\text { Two methylation-specific } \\
\text { PCR assays } \\
\text { 1) Quantitative real-time } \\
\text { PCR (Vlassenbroeck et al. } \\
\text { [10]); } 182 \text { samples } \\
\text { 2) Conventional methyla- } \\
\text { tion-specific PCR (Felsberg } \\
\text { et al.[2]); same } 182 \text { samples } \\
\text { and } 70 \text { additional samples } \\
\text { from stereotactic biopsies) } \\
\text { In case of conflicting results } \\
\text { (4 samples), results from } \\
\text { real-time PCR were used }\end{array}$ & $\begin{array}{l}\text { 1) MDxHealth, Liège, } \\
\text { Belgium (quantitative real- } \\
\text { time PCR) } \\
\text { 2) Brain Tumor Reference } \\
\text { Centre, Germany (conven- } \\
\text { tional methylation-specific } \\
\text { PCR) }\end{array}$ & $\geq 80 \%$ & $\begin{array}{l}56 \%(209 / 373 \\
\text { patients) }\end{array}$ \\
\hline $\begin{array}{l}\text { Nordic Trial } \\
\text { (Malmström et } \\
\text { al. [5]) }\end{array}$ & $\begin{array}{l}\text { Only patients } \\
\text { with histologi- } \\
\text { cally confirmed } \\
\text { GBM eligible }\end{array}$ & $\begin{array}{l}\text { CpG 75-79 and } \\
\text { CpG 87-89 }\end{array}$ & $\begin{array}{l}\text { Quantitative real-time PCR } \\
\text { (Vlassenbroeck et al. [10]) }\end{array}$ & $\begin{array}{l}\text { MDxHealth, Liège, Bel- } \\
\text { gium }\end{array}$ & $\begin{array}{l}\text { Not speci- } \\
\text { fied }\end{array}$ & $\begin{array}{l}59 \%(203 / 342 \\
\text { patients) }\end{array}$ \\
\hline $\begin{array}{l}\text { EORTC 26981 } \\
\text { (Hegi et al. [4]; } \\
\text { Stupp et al. [8]) }\end{array}$ & $\begin{array}{l}\text { Only patients } \\
\text { with histologi- } \\
\text { cally confirmed } \\
\text { GBM eligible }\end{array}$ & $\begin{array}{l}\text { CpG 75-79 and } \\
\text { CpG 83-86 }\end{array}$ & $\begin{array}{l}\text { Nested Methylation-Specific } \\
\text { PCR }\end{array}$ & $\begin{array}{l}\text { Laboratory of Tumor Biol- } \\
\text { ogy and Genetics, Depart- } \\
\text { ment of Neurosurgery, } \\
\text { Lausanne, Switzerland }\end{array}$ & $\begin{array}{l}\text { Not } \\
\text { specified } \\
\text { (adequate } \\
\text { tissue not } \\
\text { available } \\
\text { in } 266 \text { pa- } \\
\text { tients) }\end{array}$ & $\begin{array}{l}36 \%(206 / 573 \\
\text { patients) }\end{array}$ \\
\hline Felsberg et al. [3] & GBM & $\begin{array}{l}\text { 1) CpG 73-76 } \\
\text { and CpG 86-88 } \\
\text { 2) CpG 73-77 }\end{array}$ & $\begin{array}{l}\text { 1) Conventional methyl- } \\
\text { ation-specific PCR ( } 80 / 80 \\
\text { patients) } \\
\text { 2) Pyrosequencing ( } 48 / 80 \\
\text { patients; Qiagen PyroMark } \\
\text { Q24 MGMT kit) }\end{array}$ & $\begin{array}{l}\text { Brain Tumor Reference } \\
\text { Center, Düsseldorf, Ger- } \\
\text { many }\end{array}$ & $\begin{array}{l}\geq 80 \% \text { (all } \\
\text { except for } \\
3 \text { of } 80 \text { pa- } \\
\text { tients) }\end{array}$ & $\begin{array}{l}100 \%(80 / 80 \\
\text { patients); } 70 / 80 \\
\text { frozen tissue } \\
\text { sections; } 10 / 80 \\
\text { formalin-fixed and } \\
\text { paraffin-embed- } \\
\text { ded tissue }\end{array}$ \\
\hline Shah et al. [7] & GBM & $\begin{array}{l}\text { 1) All } 97 \text { CpG } \\
\text { sites } \\
\text { 2) CpG 8, CpG } 22 \\
\text { and CpG } 80\end{array}$ & $\begin{array}{l}\text { 1) Quantitative bisulfite } \\
\text { sequencing } \\
\text { 2) Methylation-specific mul- } \\
\text { tiplex ligation-dependent } \\
\text { probe amplification }\end{array}$ & $\begin{array}{l}\text { Swedish Neuroscience } \\
\text { Insti-tute, Seattle, USA }\end{array}$ & $\begin{array}{l}\text { Not speci- } \\
\text { fied }\end{array}$ & $\begin{array}{l}100 \%(70 / 70) \\
\text { frozen tissue sec- } \\
\text { tions] }\end{array}$ \\
\hline
\end{tabular}

interpreted in terms of the particular method used and the specific methylation sites assessed. In our opinion, it is therefore problematic to transfer the significance of the MGMT status as defined in the aforementioned studies to alternative methods or different methylation sites in an uncritical manner. The different methods and CpG sites studied in the cited publications are listed in $\bullet$ Tab. 1.

- The previously published studies of MGMT promoter methylation status set high standards for the sample materials used for analysis. In the NOA08 study, for example, only those tissue samples with a tumor cell con- tent of at least $80 \%$ were accepted for analysis [11]. In our experience, this restricts the possibility of determining the MGMT status in practice to just 40 to $60 \%$ of all GBM patients. The tumor cell content of the remaining samples will be too low to ensure the reliable determination of MGMT promoter methylation status under the present conditions. Currently available studies show similarly low rates of analysis (• Tab. 1). Furthermore, the two studies with a $100 \%$ success rate used frozen tissue sections, which are not always available in routine practice. This means that, in clinical practice, the MGMT promoter meth- ylation status cannot be determined in a significant proportion of patients due to a lack of suitable sample material.

- In the EORTC-26981-22981/NCICCE3 study [9], the addition of temozolomide to radiotherapy resulted in a small, yet statistically significant survival benefit for GBM patients with an unmethylated MGMT status. This implies that MGMT-negative GBM patients might also benefit from temozolomide. It would thus seem that MGMT status does not play a relevant role in treatment decisions for patients $<70$ years of age (Stupp et al. included patients $<70$ years in their 
2005 study). On the other hand, the studies by Wick et al. [11] and Malmström et al. [5] provided evidence demonstrating the predictive value of MGMT status in elderly patients treated with temozolomide alone, whereas the effect of radiotherapy was independent of the MGMT status. Combined treatment with temozolomide and radiotherapy has not yet been tested in this age group. In our opinion, it is therefore not possible to draw reliable conclusions regarding the treatment of elderly GBM patients using this approach.

Taken together, these arguments suggest that:

- MGMT promoter methylation status cannot be reliably determined at all routine laboratories at the present time.

- It is unclear which method and which tumor material should or could be used.

- It is unclear which methylation sites allow a reliable predictive and/or prognostic assessment.

- There are still too few independent studies on the prognostic and predictive value of MGMT promoter gene methylation to permit its use in treatment decisions relating to the use of combined radiotherapy and chemotherapy in elderly GBM patients.

Therefore, it is imperative that well-defined and reproducible conditions for the determination of MGMT promoter methylation status are established prior to the introduction of MGMT status in routine diagnostics and daily clinical practice (e.g., when making treatment decisions for older GBM patients).

From a radio-oncological perspective, it is necessary to clearly identify the treatment regimens (e.g., combined radiotherapy and chemotherapy) in which MGMT status is really significant.

We are confident that MGMT status can play an important role in individualized treatment planning for GBM in the future. However, its precise role remains to be clarified in further studies. At present, routine use of MGMT status should be exercised with extreme caution as it is subject to the aforementioned limitations and difficulties associated with the interpretation of the results.

\section{Corresponding address}

\section{Prof. Dr. R. Fietkau}

Klinik für Strahlentherapie

Universitätsstr. 27, 91054 Erlangen

Germany

sekretariat.strahlenklinik@uk-erlangen.de

\section{Compliance with ethical guidelines}

Conflict of interest. R. Fietkau, F. Putz, G. Lahmer, S. Semrau and R. Buslei state that there are no conflicts of interest.

\section{References}

1. Berghoff AS, Stefanits H, Woehrer A et al. (2013) Clinical neuropathology practice guide 3-2013: levels of evidence and clinical utility of prognostic and predictive candidate brain tumor biomarkers. Clinical Neuropathology 32:148-158

2. Felsberg J, Rapp M, Loeser S et.al. (2009)Prognostic significance of molecular markers and extent of resection in primary glioblastoma patients. Clin Cancer Res 15:6683-93.

3. Felsberg J, Thon N, Eigenbrod S et al. (2011) Promoter methylation and expression of MGMT and the DNA mismatch repair genes MLH1, MSH2, MSH6 and PMS2 in paired primary and recurrent glioblastomas. International journal of cancer. Journal international du cancer 129:659-670

4. Hegi ME, Diserens AC, Gorlia T et al. (2005) MGMT gene silencing and benefit from temozolomide in glioblastoma. The New England Journal of Medicine 352:997-1003

5. Malmstrom A, Gronberg BH, Marosi C et al. (2012) Temozolomide versus standard 6-week radiotherapy versus hypofractionated radiotherapy in patients older than 60 years with glioblastoma: the Nordic randomised, phase 3 trial. The Lancet Oncology 13:916-926

6. Platten M, Steinbach JP, Wick W (2013) [Personalized neurooncology]. Der Nervenarzt 84:937-42

7. Shah N, Lin B, Sibenaller Z et al. (2011) Comprehensive analysis of MGMT promoter methylation: correlation with MGMT expression and clinical response in GBM. PloS one 6:e16146

8. Stupp R, Hegi ME, Mason WP et al. (2009) Effects of radiotherapy with concomitant and adjuvant temozolomide versus radiotherapy alone on survival in glioblastoma in a randomised phase III study: 5-year analysis of the EORTC-NCIC trial. The Lancet Oncology 10:459-466

9. Stupp R, Weber DC (2005) The role of radio- and chemotherapy in glioblastoma. Onkologie 28:315-317

10. Vlassenbroeck I, Califice $S$, Diserens $A C$ et al. (2008) Validation of Real-Time MSP to Determine MGMT Promoter Methylation in Glioma. J Mol Diagn 10:332-337.
11. Wick W, Platten M, Meisner C et al. (2012) Temozolomide chemotherapy alone versus radiotherapy alone for malignant astrocytoma in the elderly: the NOA-08 randomised, phase 3 trial. The Lancet Oncology 13:707-715 